ДВНЗ “Тернопільський державний медичний університет імені I. Я. Горбачевського МОЗ Украӥни”

\title{
ДОСВІД ОСВОЄННЯ ПРАКТИЧНИХ НАВИЧОК ТА ОСОБЛИВОСТІ ІНДИВІДУАЛЬНОЇ РОБОТИ СТУДЕНТІВ 5 КУРСУ МЕДИЧНОГО ФАКУЛЬТЕТУ НА КАФЕДРІ ВНУТРІШНЬОЇ МЕДИЦИНИ № 3
}

T. V. Boyko

\author{
I. Horbachevsky Ternopil State Medical University \\ ACQUISITION EXPERIENCE OF PRACTICAL HABITS AND \\ PECULIARITIES OF INDIVIDUAL 5 COURSE STUDENTS' WORK \\ OF THE MEDICAL FACULTY AT THE INTERNAL MEDICINE \\ DEPARTMENT NO. 3
}

\begin{abstract}
Мета роботи - вивчити досвід освоєння практичних навичок та особливості організації індивідуальної роботи студентів (IPC) на кафедрі внутрішньої медицини № 3.

Основна частина. Відпрацювання в умовах відділень терапевтичного профілю є дієвим та перспективним методом передачі навчальної інформації шляхом практичних дій. Максимально наближені до реальних умов практичні заняття та позааудиторна робота студентів підвищують їх мотивацію та зацікавленість до самостійного виконання практичних навичок.

IPC - це самостійне освоєння студентом частини навчальної програми, що здійснюється за партнерської участі викладача в її плануванні і оцінці досягнення конкретного результату. При організації ІРС співробітники кафедри внутрішньої медицини № 3 враховують індивідуальні здібності студента, допомагають розкрити його творчий потенціал, кращі якості як майбутнього лікаряфахівця. Контроль IPC проводиться шляхом усного опитування та виконання письмових контрольних завдань під час практичних занять, проміжного та поточного контролю. При контролі засвоєння матеріалу при IРС викладач оцінює не тільки рівень освоєння студентом навчального матеріалу, а і його вміння використовувати отримані знання при постановці діагнозу. Необхідно враховувати чіткість викладу й обгрунтованість відповіді, рівень володіння матеріалом, наявність творчого підходу при IPC, ступінь уявлення студента про нові медичні технології, знання показань та протипоказань до призначення лікування. Види ІРС, що використовуються при викладанні предмета внутрішньої медицини на кафедрі внутрішньої медицини № 3 ТДМУ студентам п’ятого курсу, - це IPC на аудиторних заняттях, позааудиторна IPC, самостійна робота під контролем викладача (індивідуальні заняття з викладачем).

Висновок. Організація IPC сприяє повноціннішому засвоєнню матеріалу та формуванню знань і умінь, що допомагає у підготовці кваліфікованих лікарів європейського рівня.
\end{abstract}

Ключові слова: індивідуальна робота студентів; навчання; знання; практичні навички.

The aim of the work - to explore the experience of the organization of student's individual work at the Department of Internal Medicine No. 3.

The main body. Working out in the conditions of the departments of the therapeutic profile is an effective and promising method for the transfer of educational information in a way of practical action. Practical classes and extra-curricular work of students, which are as close to actual conditions as possible, increase their motivation and interest in self-executing practical skills. Individual work of students - is an independent mastering of the student part of the curriculum, carried out in the partnership of the participant teacher in its planning and evaluation of the achievement of a specific result. During the organization of the individual student's work department's staff of the Department of Internal Medicine No. 3 consider student's individual skills, help to open up his creativity, the best qualities as the future doctor. Student's individual work control is carried by oral examination and written tests during the practical lesson, intermediate and current control. Teacher evaluates not only the level of assimilation or the learned material, but student's skill to use obtained knowledge. Clarity and validity of the answer, the level of the oral language proficiency and written layout of the material, presents of the creativity, the level of understanding of new medical technologies must be considered. Types of individual student's work, which are used during the learning process at the Department of Internal Medicine No. 3 by 5 course students, are: individual student's work on classroom lessons, extracurricular individual work, individual work under teacher's control (individual lesson with the teacher).

Conclusion. Organization of the individual student's work helps to reach a full assimilation of the material and forming skills and knowledge, which will help on training of the high-qualified European level doctors.

Key words: student’s individual work; education; knowledge; practical habits.

Вступ. Узагальнено досвід освоєння практичних навичок та особливості організації індивідуальної

(C) Т. В. Бойко роботи студентів (IPC) на кафедрі внутрішньої медицини № 3. Відпрацювання в умовах відділень терапевтичного профілю є дієвим та перспективним 
методом передачі навчальної інформації шляхом практичних дій. Максимально наближені до реальних умов практичні заняття та позааудиторна робота студентів підвищують їх мотивацію та зацікавленість до самостійного виконання практичних навичок.

IPC - це самостійне освоєння студентом частини навчальної програми, що здійснюється за партнерської участі викладача в її плануванні і оцінці досягнення конкретного результату.

При організації IPC співробітники кафедри внутрішньої медицини № 3 враховують індивідуальні здібності студента, допомагають розкрити його творчий потенціал, кращі якості як майбутнього лікаря-фахівця.

Мета роботи - вивчити досвід освоєння практичних навичок та особливості індивідуальної роботи студентів 5 курсу медичного факультету на кафедрі внутрішньої медицини № 3 .

Основна частина. IPC на всіх етапах має на увазі ділову взаємодію студента і викладача - викладач виконує управлінську та контролюючу функції, а студент дотримується вказівок і рекомендацій викладача при виконанні IPC та практичних навичок. IPC є спланованою пізнавальною, організаційно і методично спрямованою діяльністю, яка здійснюється індивідуально без допомоги викладача. Життям доведено, що тільки ті знання, які студент здобув самостійно, будуть міцні. Самостійне отримання правильної відповіді шляхом проб і помилок $є$ одним із методів формування всебічно розвиненої молодої людини. 3 метою підготовки кваліфікованого спеціаліста потрібно надавати студенту можливість самому вирішувати задачі, що виникають у процесі навчання, та виконувати їх практично. Таким методом є індивідуальна робота. Працювати самостійно особливе значення має в навчанні студентів-медиків, оскільки використовувати знання, отримані на практичних заняттях, для постановки діагнозу самостійно є дуже важливим для покращення клінічного мислення майбутнього лікаря. IPC - складне педагогічне явище, особлива форма навчальної діяльності, спрямована на формування самостійності студентів і засвоєння ними сукупності знань, умінь, навичок, що здійснюється ними за умови запровадження відповідної системи організації всіх видів навчальних занять [1, 2]. Контроль IPC проводиться шляхом усного опитування та виконання письмових контрольних завдань (у тому числі тестових) під час практичних занять, проміжного та поточного контролю. При контролі засвоєння матеріа- лу при IPC викладач обов’язково оцінює не тільки рівень освоєння студентом навчального матеріалу, a і його вміння використовувати отримані знання при виконанні практичних навичок [3, 4]. Необхідно враховувати чіткість викладу і обгрунтованість відповіді, рівень володіння усною мовою і письмовим викладенням матеріалу, наявність творчого підходу при IPC, ступінь уявлення студента про нові медичні технології, знання показань [5]. Контроль знань при IPC - це, перш за все, людське спілкування, що вимагає від викладача зосередитись, насамперед, на формі проведення контролю. 3 метою виключення проблем етичного характеру при проведенні контролю отриманих знань викладач повинен уникати упередженості і особистих конфліктів [6-8].

Види IPC, що використовуються при викладанні предмета внутрішньої медицини на кафедрі внутрішньої медицини № 3 ТДМУ студентам 5 курсу, це IPC на аудиторних заняттях, позааудиторна IPC, самостійна робота під контролем викладача (індивідуальні заняття з викладачем).

Щодня студенти виконують практичні навички: працюють з тематичними хворими і заповнюють протокол, де вказані основні моменти постановки діагнозу, призначення плану діагностичних процедур та лікування. Окрім того, студенти 5 курсу отримують пацієнта на курацію, самостійно працюють з ним, одержані дані порівнюють з написаним у книгах, проводять диференційну діагностику захворювання і призначають лікування; протягом циклу навчання спостерігають за динамікою клінічних та лабораторних показників, що дозволяє оцінити ефективність проведених маніпуляцій. Оформляють історію хвороби і захищають її у викладача. Оцінювання роботи студента проводиться за затвердженою на засіданні кафедри кредитномодульною системою.

Студенти, які хочуть поглибити свої знання 3 певних розділів внутрішньої медицини, індивідуально працюють під керівництвом викладача. Ці години є в переліку обов’язкового педагогічного навантаження і проводяться згідно з графіком, затвердженим на засіданні кафедри. Окрім цього, проводиться позааудиторна робота студентів: студенти отримують теми для позааудиторної роботи на початку семестру згідно з тематичним планом IPC та визначаються терміни виступу із презентаціями. Як свідчить наш досвід, студенти надають перевагу саме такому методу опрацювання тем для IPC. При цьому основними завданнями викладача $\epsilon$ перевірити вивчене та оцінити якість підготовки 
студента, допомогти скерувати думку в правильному напрямку, мотивувати студентів самостійно мислити і вирішувати питання планування та організації своєї навчальної діяльності.

Висновки. 1. Співробітники кафедри внутрішньої медицини № 3 всебічно сприяють формуванню у студентів клінічного мислення та оволодінню практичними навичками, необхідними в подальшій повсякденній роботі лікаря.

\section{Список літератури}

1. Впровадження новітніх технологій в навчальний процес - запорука якісної підготовки лікарів-стоматологів в умовах Європейської інтеграції / П. А. Гасюк, Н. В. Гасюк, Д. Д. Кіндій [та ін.] // Європейський вибір невід'ємна складова розвитку вищої медичної освіти України : матеріали навч.-метод. конф., Полтава, 23 травня 2013 р. - Полтава, 2013. - С. 31-32.

2. Положення про організацію освітнього процесу в Державному вищому навчальному закладі “Івано-Франківський національний медичний університет”. - ІваноФранківськ, 2015. - 76 с.

3. Сікорська М. В. Проблема відпрацювання практичних навиків при вивченні нервових хвороб іноземними студентами / М. В. Сікорська, I. В. Візір // Сучасні підходи до вищої медичної освіти в Україні : матеріали Всеукр. наук.-практ. конф. з міжнар. участю, присвяченої 60-річчю ТДМУ, Тернопіль, 18-19 травня 2017 р. Тернопіль, 2017. - Т. 2. - С. 134.

4. Оптимізація практичних методів навчання у професійній підготовці студентів медичного університету / Т. І. Гриджук, Т. В. Мергель, У. В. Юсипчук [та ін.] // Сучасні підходи до вищої медичної освіти в Україні : матеріали Всеукр. наук.-практ. конф. з міжнар. участю,
2. Організація індивідуальної роботи студентів вимагає не тільки методологічного забезпечення 3 боку викладачів кафедри, але і постійної взаємодії викладача та студента на основі партнерства, дає можливість здобути якісні знання, професійні вміння та навички, що допомагає у підготовці майбутніх кваліфікованих лікарів-професіоналів європейського рівня.

присвяченої 60-річчю ТДМУ, Тернопіль, 18-19 травня 2017 р. - Тернопіль, 2017. - Т. 1. - С. 39.

5. Макойда I. Я. Самостійна робота студентів - метод підготовки висококваліфікованого спеціаліста / I. Я. Макойда, М. М. Островський // Галицький лікарський вісник. - 2013. - № 4. - С. 87-88.

6. Скробач Н. В. Самостійна робота студентів вищих навчальних закладів як важливий елемент сучасної підготовки фахівців / Н. В. Скробач, І. Т. Гаврик, Ю. В. Дельва // Галицький лікарський вісник. - 2014. № 2. - С. 110-111.

7. Чорній Н. В. Самостійна робота студентів як складова частина у підготовці спеціаліста в умовах кредитномодульної системи навчання / Н. В. Чорній // Медична освіта. - 2014. - № 4. - С. 132-134.

8. Боднарчук О. В. Роль самостійної роботи при вивченні органічної хімії в умовах кредитно-модульної системи / О. В. Боднарчук, А. О. Стецьків // Досвід впровадження кредитно-модульної системи організації навчального процесу у вищих навчальних закладах Прикарпаття III-IV рівнів акредитації : матеріали наук.-метод. конф., 29 квітня 2015 р. - Івано-Франківськ, 2015. - С. 17-18.

[Regulations on the organization of educational process at the State Higher Educational Institution "Ivano-Frankivsk National Medical University”]. Ivano-Frankivsk [in Ukrainian].

3. Sikorska, M.V., \& Vizir, V. (2017). Problema vidpratsiuvannia praktychnykh navykiv pry vyvchenni nervovykh khvorob inozemnymy studentamy [The problem of working out practical skills in the study of nerve diseases by foreign students]. Materialy Vseukrainskoi naukovopraktychnoi konferentsii z mizhnarodnoiu uchastiu, prysviachenoi 60-richchiu TDMU. "Suchasni pidkhody do vyshchoi medychnoi osvity v Ukraini”, 18-19 travnia 2017, Ternopil - Materials of the All-Ukrainian Scientific and Practical Conference with International Participation devoted to the 60th anniversary of the TDMU. Modern Approaches to Higher Medical Education in Ukraine, May 18-19. Ternopil [in Ukrainian]. 
4. Hrydzhuk, T.I., Merhel, T.V., Yusypchuk, U.V., Sarapuk, O.R., Hlushko, N.L., Sarapuk, I.V., \& Savchuk, N.V. (2017). Optymizatsiia praktychnykh metodiv navchannia u profesiinii pidhotovtsi studentiv medychnoho universytetu [Optimization of practical methods of teaching in the professional training of students of the medical university]. Materialy Vseukrainskoi naukovo-praktychnoi konferentsii z mizhnarodnoiu uchastiu, prysviachenoi 60-richchiu TDMU. "Suchasni pidkhody do vyshchoi medychnoi osvity v Ukraini”, 18-19 travnia 2017, Ternopil - Materials of the All-Ukrainian Scientific and Practical Conference with International Participation devoted to the 60th anniversary of the TDMU. Modern Approaches to Higher Medical Education in Ukraine, May 18-19. Ternopil [in Ukrainian].

5. Makoida, I.Ya., \& Ostrovskyi, M.M. (2013). Samostiina robota studentiv - metod pidhotovky vysokokvalifikovanoho spetsialista [Independent work of students - the method of preparation of a highly skilled specialist]. Halytskyi likarskyi visnyk - Galician Medical Journal, (4), 87-88 [in Ukrainian].

6. Skrobach, N.V., Havryk, I.T., \& Delva, Yu.V. (2014). Samostiina robota studentiv vyshchykh navchalnykh zakladiv yak vazhlyvyi element suchasnoi pidhotovky fakhivtsiv [Independent work of students of higher educational institutions as an important element of modern training of specialists]. Halytskyi likarskyi visnyk - Galician Medical Journal, (2), 110-111 [in Ukrainian].

7. Chornii, N.V. (2014). Samostiina robota studentiv yak skladova chastyna u pidhotovtsi spetsialista $\mathrm{v}$ umovakh kredytno-modulnoi systemy navchannia [Independent work of students as an integral part in the training of a specialist in the conditions of credit-transfer system of education]. Medychna osvita - Medical Education, (4), 132-134 [in Ukrainian]. DOI: http://dx.doi.org/10.11603/me.v0i4.3703.

8. Bodnarchuk, O.V., \& Stetskiv, A.O. (2015). Rol samostiinoi roboty pry vyvchenni orhanichnoi khimii v umovakh kredytno-modulnoi systemy [The role of independent work in the study of organic chemistry under the conditions of the credit-transfer system]. Dosvid vprovadzhennia kredytno-modulnoi systemy orhanizatsii navchalnoho protsesu u vyshchykh navchalnykh zakladakh Prykarpattia III-IV rivniv akredytatsii: naukovo-metodychna konferentsiia 29 kvitnia 2015 r.: tezy dop. - Experience of introduction of credit-transfer system of organization of educational process in higher educational institutions of Prykarpattia III-IV levels of accreditation: scientificmethodical conference April 29, 2015: theses additional, Ivano-Frankivsk, 17-18 [in Ukrainian]. 